\title{
Hypothalamic Control of Lipid Metabolism: Focus on Leptin, Ghrelin and Melanocortins
}

\author{
Carlos Diéguez ${ }^{\mathrm{a}, \mathrm{b}}$ María J. Vazquez ${ }^{\mathrm{a}, \mathrm{b}}$ Amparo Romero ${ }^{\mathrm{a}, \mathrm{b}}$ Miguel López $^{\mathrm{a}, \mathrm{b}}$ \\ Ruben Nogueiras ${ }^{a, b}$ \\ a Department of Physiology, School of Medicine, Instituto de Investigacion Sanitaria (IDIS), University of Santiago \\ de Compostela, ${ }^{b}$ CIBER Fisiopatología de la Obesidad y Nutrición (CIBERobn), Santiago de Compostela, Spain
}

\section{Key Words}

Hypothalamus · AMP-activated protein kinase $\cdot$

Sympathetic nervous system

\begin{abstract}
The hypothalamus plays a crucial role in the regulation of food intake and energy expenditure. One of the main regulatory factors within the hypothalamus is AMP-activated protein kinase (AMPK), which is involved in a large number of biological actions including the modulation of energy balance. Leptin and ghrelin-induced changes in hypothalamic AMPK lead to important alterations in hypothalamic fatty acid metabolism. Furthermore, it is well known that the hypothalamus controls peripheral lipid metabolism through the sympathetic nervous system, and those actions are independent of food intake. In this short review, we highlight the main molecular pathways triggered by leptin and ghrelin altering both central and peripheral lipid metabolism and, therefore, controlling feeding behavior and energy expenditure.

Copyright $\odot 2011$ S. Karger AG, Basel
\end{abstract}

\section{KARGER}

Fax +4161306 1234

E-Mail karger@karger.ch

www.karger.com
(C) 2011 S. Karger AG, Basel

0028-3835/11/0941-0001\$38.00/0

Accessible online at:

www.karger.com/nen

\section{Introduction}

The central nervous system (CNS) modulates energy balance by regulating food intake and energy expenditure in response to hormones as well as neuronal or nutrient signals. Although several regions of the CNS participate in these actions, the most frequently studied is perhaps the hypothalamus. The hypothalamus is constituted in anatomically defined neuronal clusters, called nuclei, forming interconnected neuronal circuits via axonal projections. Hypothalamic nuclei are sensitive to nutrients and hormones and modify the expression, secretion and activity of specific neurotransmitters and neuromodulators, resulting in changes in energy intake and energy expenditure [1]. In mammals, neurons, particularly in the arcuate nucleus of the hypothalamus (ARC), are involved in the regulation of energy homeostasis [2]. One regulatory pathway consists of neurons co-expressing neuropeptide Y (NPY) and agouti-related protein (AgRP), both potent stimulators of food intake, and an adjacent set of ARC neurons co-express proopiomelanocortin (POMC) and cocaine- and amphetamine-regulated transcript (CART), which suppress food intake [3]. These cells 
respond to signals on both the long- and short-term energy status of the animal. Leptin, secreted by, and in proportion to white adipose tissue (WAT), signals the status of energy stores and activates POMC/CART neurons and inhibits NPY/AgRP neurons, resulting in inhibition of feeding and an increase in energy expenditure $[4,5]$. Ghrelin is secreted mainly by the stomach, but is also present in the hypothalamus, and activates NPY/AgRP neurons stimulating feeding and decreasing energy expenditure [6]. Hypothalamic neurons respond to peripheral signals such as glucose, leptin, ghrelin, adiponectin, resistin and insulin by modifying the synthesis of the neuropeptides described above. Recent reports also show that specific pathways in the CNS are also directly connected to WAT, brown adipose tissue and liver, thereby directly influencing adipocyte and hepatic metabolism [7-11].

\section{Hypothalamic Lipid Metabolism Modulates Energy Homeostasis}

There are numerous reports demonstrating that hypothalamic lipid metabolism is a crucial mechanism regulating energy homeostasis. Anatomical data show that key enzymes modulating lipid metabolism, such as AMPactivated protein kinase (AMPK), acetyl-CoA carboxylase (ACC), carnitine palmitoyltransferase 1 (CPT1), fatty acid synthase (FAS) and malonyl-CoA decarboxylase, are found in high levels in hypothalamic nuclei including ARC, dorsomedial, paraventricular (PVH) and ventromedial $(\mathrm{VMH})$ nuclei, which are closely related with the regulation of food intake and energy expenditure [12]. Treatments with FAS inhibitors, such as cerulenin and C75, or drugs that decrease FAS expression, like tamoxifen, cause suppression of food intake and the loss of body weight [13-15]. The anorectic effect of these drugs requires the accumulation of malonyl-CoA in the hypothalamus, which may be sensed as a signal of nutrient abundance by critical neurons regulating food intake ('malonyl-CoA hypothesis') [13] and decreased expression of orexigenic (AgRP and NPY) and elevated expression of anorexigenic (CART, POMC) neuropeptides in the ARC [13]. Hypothalamic malonyl-CoA is also modulated by nutritional status. Fasting reduces the production of hypothalamic malonyl-CoA $[13,15,16]$, reprogramming metabolic substrate utilization away from glycolysis and toward lipid oxidation [17].

There are two potential theories that may explain the molecular pathways mediating the actions of FAS inhibi- tors. The first theory suggests that malonyl-CoA or a derivative interacts directly with a signaling protein that regulates expression of neuropeptides. This is the case in mice lacking FAS in the hypothalamus, which are leaner and hypophagic [18]. They also present with increased hypothalamic levels of malonyl-CoA and impaired expression of ARC-derived neuropeptides [18]. Similar findings were obtained after genetic disruption of hypothalamic AMPK by using adenoviruses, which decrease food intake $[16,19]$. The second theory suggests that malonyl-CoA acts indirectly on CPT1, and thus prevents the access of long-chain fatty acyl-CoA to the mitochondria, which would decrease food intake. This theory is demonstrated by the fact that pharmacological inhibition or genetic ablation of hypothalamic CPT1 activity inhibits feeding [20-22], indicating that the accumulation of fatty acyl-CoA is the mediator in the signaling pathway modulating feeding.

Physiological findings have also shown that regulation of hypothalamic fatty acid metabolism is part of the adaptive changes observed during physiological regulation of feeding. Fasting stimulates hypothalamic AMPK and inhibits ACC and FAS activities, whereas re-feeding induces opposite changes [15, 16, 19, 23]. Furthermore, hypothalamic AMPK and consequently, ACC and FAS activities, are modulated by peripheral signals that are crucial for the regulation of energy balance. Anorectic hormones, such as leptin, insulin, glucagon-like peptide-1, ciliary neurotrophic factor and melanocortin receptors agonists (e.g. melanotan II), inhibit hypothalamic AMPK and activate ACC and/or FAS [12]. On the other hand, orexigenic signals, such as cannabinoids, glucocorticoids, adiponectin, ghrelin and AgRP, activate AMPK and inhibit ACC and FAS [12]. Of note, rather than feeding, thyroid hormones control brown adipose tissue thermogenesis through specific action on AMPK in the VMH [24]. In addition to hormonal signals and neuropeptides, hypothalamic AMPK and ACC are also modulated by nutrients and intermediate metabolites, including glucose $[19,25,26], \alpha$-lipoic acid [27], citrate [28] and lactate [29].

Finally, it is important to mention that hypothalamic fatty acids not only play an important role within the CNS, but peripheral fatty acids also exert a key signaling role on hypothalamic neurons. Most importantly, the impairment of this process could be involved in obesity development and/or maintenance [30]. 


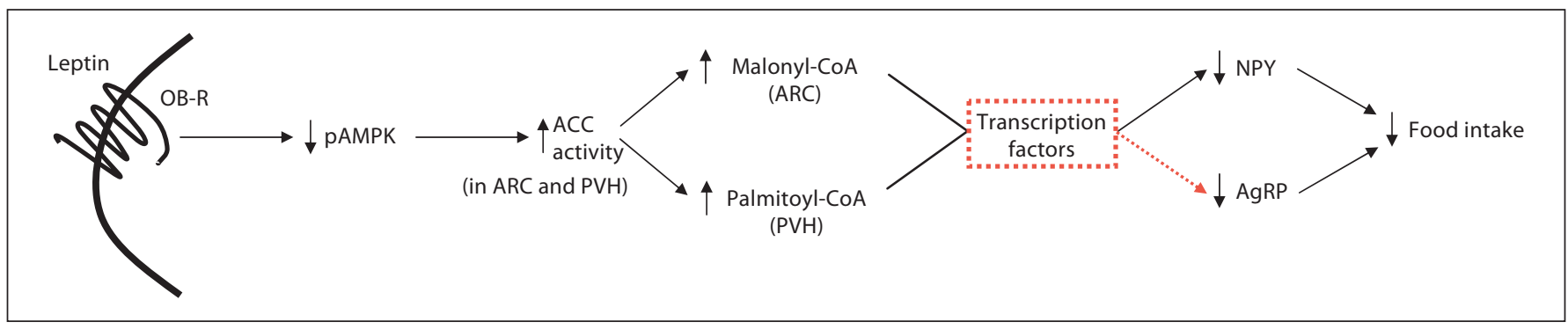

Fig. 1. CNS leptin modulates hypothalamic fatty acid metabolism, leading to stimulation or suppression of food intake respectively. The hypothalamic AMPK-fatty acid pathway seems to be essential for both hormones, and changes in malonyl-CoA and palmitoyl-CoA precede the inhibition of NPY. The red square and red arrow indicate the hypothetical molecular steps which have not been described. OB-R = Leptin receptor.

\section{CNS Leptin and Hypothalamic Lipid Metabolism}

Leptin is a satiety hormone, secreted by, and in proportion to adipose tissue, informing the hypothalamus of the status of energy stores $[31,32]$. One of the factors required by leptin to exert its anorectic effect is hypothalamic AMPK (fig. 1). This was demonstrated by injecting leptin into fasted mice expressing the dominant negative or constitutively active AMPK in the medial hypothalamus. Leptin decreased body weight and food intake in control mice and mice expressing dominant negative AMPK, but failed to do so in mice expressing constitutively active AMPK [19]. This indicates that suppression of AMPK activity in the medial hypothalamus is necessary for leptin's anorexic and weight loss effects and that lack of suppression causes leptin resistance [19]. The inhibition of AMPK caused by central injection of leptin activates ACC in the ARC and the PVH of the hypothalamus [23]. Consistently, the overexpression of constitutively active AMPK in the ARC blunts the activation of ACC in the ARC in response to central leptin, reinforcing the hypothesis that AMPK is upstream of ACC in the leptin receptor-mediated intracellular signaling pathway [23]. Accordingly, the inhibition of hypothalamic ACC blocks the actions of leptin on feeding behavior, body weight and NPY mRNA expression [23]. Overall, these results show that hypothalamic ACC is an essential modulator of leptin's effects. Furthermore, intracerebroventricular leptin increases malonyl-CoA levels specifically in the ARC and increases the level of palmitoyl-CoA specifically in the PVH [23]. Although the role of fatty acids as mediators of the actions of leptin is well documented, the precise molecular events occurring after the changes in malonyl-CoA and before NPY activation are still unknown and deserve further attention (fig. 1).

Hypothalamic Control of Lipid Metabolism

\section{CNS Leptin Action and Peripheral Lipid Metabolism}

Leptin is an adipocyte-derived satiety hormone whose effects are mediated by neuronal pathways. The leptin receptor is expressed in several brain areas that mediate the central actions of leptin. Leptin induces opposite effects on two ARC neuronal subpopulations: it directly inhibits the orexigenic NPY/AgRP-containing neurons and it stimulates the electrical activity of anorexigenic POMC neurons [4] (fig. 2). After the discovery of its anorectic role, it was demonstrated that leptin also regulated peripheral lipid and glucose metabolism [33-35]. In vivo studies revealed that leptin treatment stimulated lipolytic action in adipose tissues [36]. Later reports showed that central leptin infusion into the mediobasal hypothalamus of rats inhibited the synthesis of lipids in WAT [37]. For instance, 4-day central infusion of leptin decreased the expression of stearoyl-CoA-desaturase-1 (fig. 2), the rate-limiting enzyme during de novo conversion of saturated fatty acids to the monounsaturated fatty acids in WAT [38]. Similar data were obtained after 1 week of treatment [39]. Another study showed that the administration of leptin into the third cerebral ventricle increased the gene expression of hormone-sensitive lipase, a marker of lipolysis, in WAT [40] (fig. 2). Overall, it can be concluded that leptin, acting at the central level, decreases fat tissue mass and lipid accumulation. The lipolytic actions of CNS leptin on adipocyte metabolism require intact autonomic innervation because sympathetic denervation of adipose tissue abolished leptin's effects [37]. The signal transduction pathway mediating the lipolytic action of central leptin is phosphoinositide 3-kinase, but not the signal transducer and activator of transcription 3 [37] (fig. 2). This was demonstrated by the administration of specific antagonists for both transcription factors, and

Neuroendocrinology 2011;94:1-11 


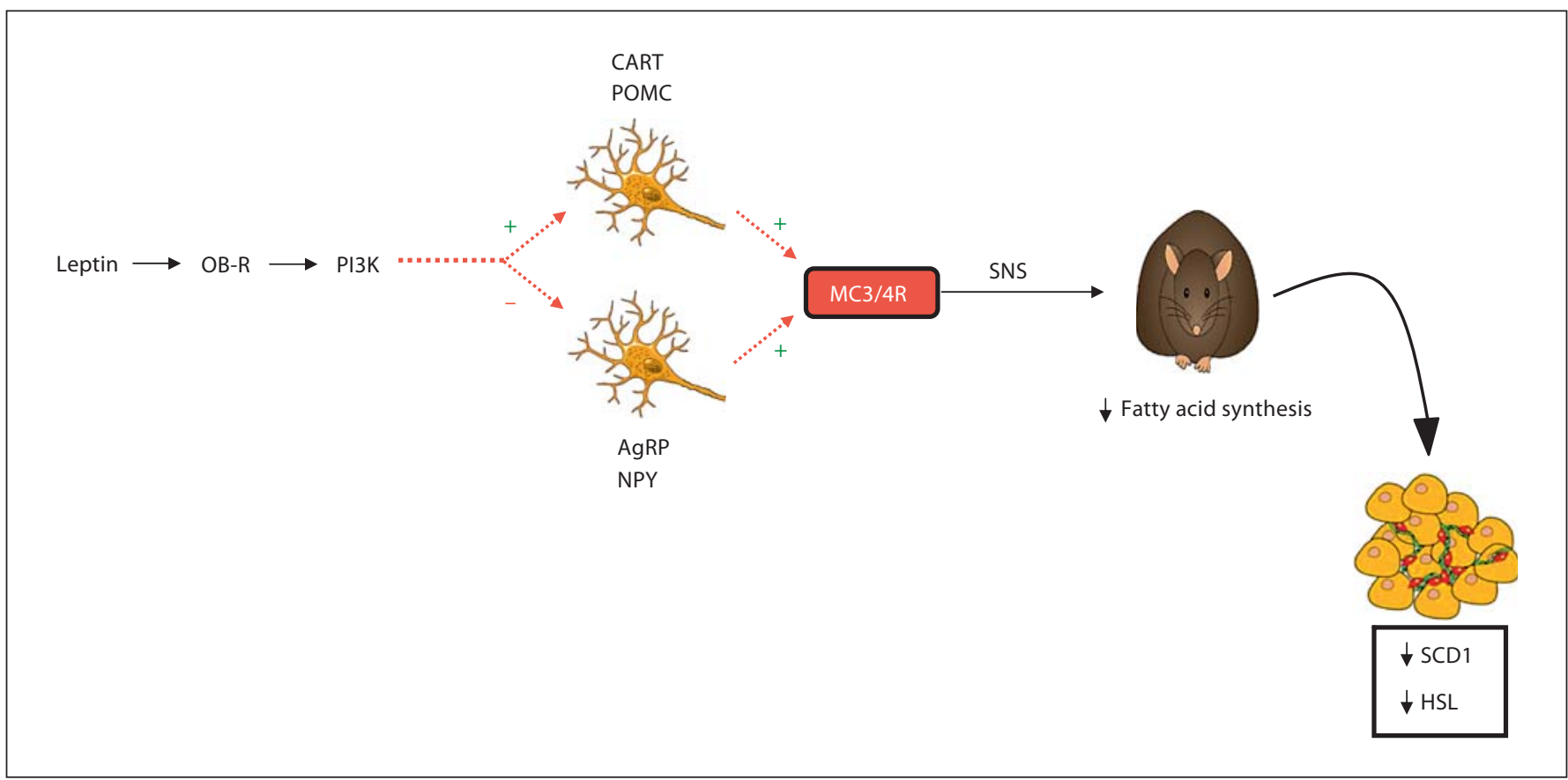

Fig. 2. CNS leptin decreases peripheral lipid deposition. Leptin requires phosphoinositide 3 -kinase (PI3K) to modulate adipocyte metabolism, and hypothalamic neuropeptides (NPY/AgRP vs. $\mathrm{POMC/CART)}$, and thereby melanocortin receptors, are likely to be involved in the lipolytic action of leptin. Red arrows indicate the hypothetical molecular steps which have not been described for the lipolytic action of leptin. OB-R = Leptin receptor; SNS = sympathetic nervous system; SCD1 = stearoyl-CoA-desaturase-1; $\mathrm{HSL}=$ hormone-sensitive lipase. the results indicated that only inhibitors of phosphoinositide 3-kinase blocked the central action of leptin, whereas the blockade of the signal transducer and activator of transcription 3 did not modify the lipolytic effects of leptin [37]. However, it is important to point out that one study suggests that leptin regulates peripheral lipid metabolism through its anorexigenic action [41]. Although definitive proof is lacking, it is possible that the loss of adipose tissue in treated patients with mutations of the leptin-gene could be mediated by leptin's effects on food intake as well as by its lipolytic action exerted at the central level.

Indeed, all the studies concerning the actions of leptin on fatty acid metabolism have been done using rodents fed on standard diet. It is well known that the development of obesity and leptin resistance in rodents on highfat diets is divided into three steps. In the initial stage, the mice gain fat but leptin is still effective in decreasing food intake. In the middle stage, rodents lose peripheral leptin sensitivity while central leptin is still active. In the latter stage, mice also develop central leptin resistance [42]. There are two hypotheses to explain this leptin resis- tance. One refers to the failure of circulating leptin to reach the CNS [43] and the other suggests that there is a failure in the leptin receptor signaling pathway [44]. Although the effects of leptin on fatty acid metabolism have not been studied according to the stages of leptin resistance, it is reasonable to hypothesize that its lipolytic actions would work similarly to its anorectic effect.

\section{CNS Ghrelin and Hypothalamic Lipid Metabolism}

Ghrelin is a hormone produced in the stomach that increases food intake $[6,45]$. Since its discovery in 1999, it has been studied as a potential anti-obesity therapeutic target because central and peripheral ghrelin administration induces weight gain and adiposity in rodents [45]. In humans, ghrelin also stimulates voluntary food intake [46]. Regarding its regulation, circulating ghrelin levels are decreased in human and rodent obesity [47] and are elevated in patients with anorexia nervosa or animals after fasting or in states of cachexia [48]. Moreover, subjects with a low BMI have higher ghrelin levels than lean sub- 


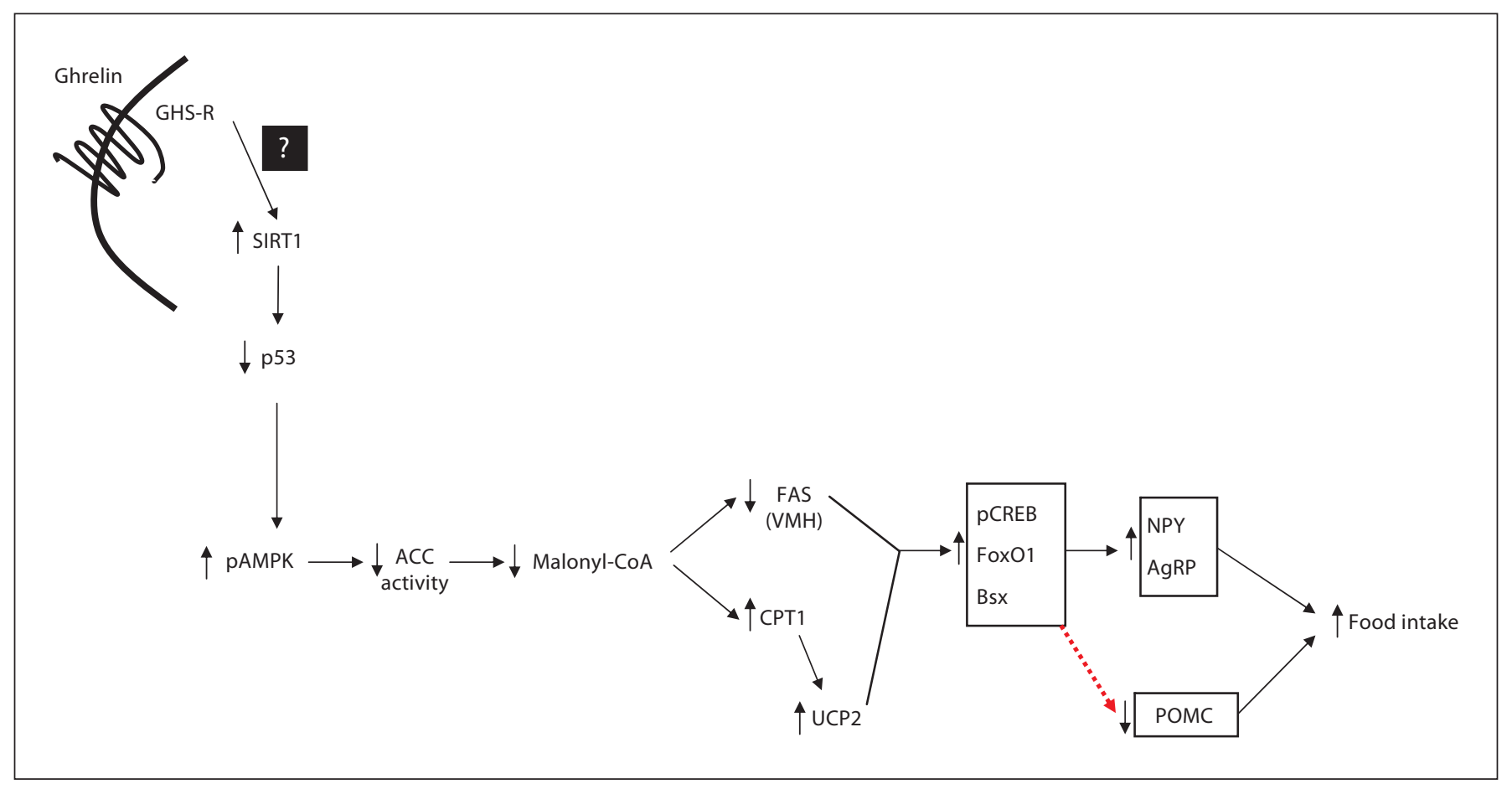

Fig. 3. CNS ghrelin activates sirtuin 1 (SIRT1) and AMPK, thereby modulating hypothalamic fatty acid metabolism and leading to stimulation of transcription factors essential for NPY/AgRP, which ultimately affects food intake. The red arrow indicates the hypothetical molecular step which has not been described. The question mark indicates a black box in the molecular events triggered after the activation of the GHS-R1 and before sirtuin 1 . UCP2 = Uncoupling protein 2; pCREB = phosphorylated cAMP response-element binding protein; FoxO1 = forkhead box $\mathrm{O} 1$.

In regard to its biological actions, ghrelin increases food intake through GHS-R la (fig. 3), as demonstrated in mice deficient in GHS-R1a, which do not respond to exogenously administered ghrelin in terms of food intake [55]. GHS-R1a is expressed in NPY/AgRP neurons in the hypothalamic ARC $[56,57]$, indicating that this set of neurons is involved in ghrelin action. Along these lines, adult male rats (fed or fasted) treated centrally (intracerebroventricular) with ghrelin showed increased AgRP and NPY electrical activity and expression in the ARC $[6,58]$ (fig. 3). Contrarily, ghrelin inhibits the activity of POMC neurons by increasing the inhibitory tone onto them [58]. The physiological relevance of both neuropeptides as mediators of ghrelin effects was firmly established by assessing the response to ghrelin in $\mathrm{KO}$ mice. These elegant experiments indicated that while NPY KO or AgRP KO showed a normal response in terms of food intake to ghrelin, the double KO NPY/AgRP failed to show any response, evidencing the existence of redundancy among these two neuropeptides as mediators of ghrelin orexigenic action [59].

Neuroendocrinology 2011;94:1-11 


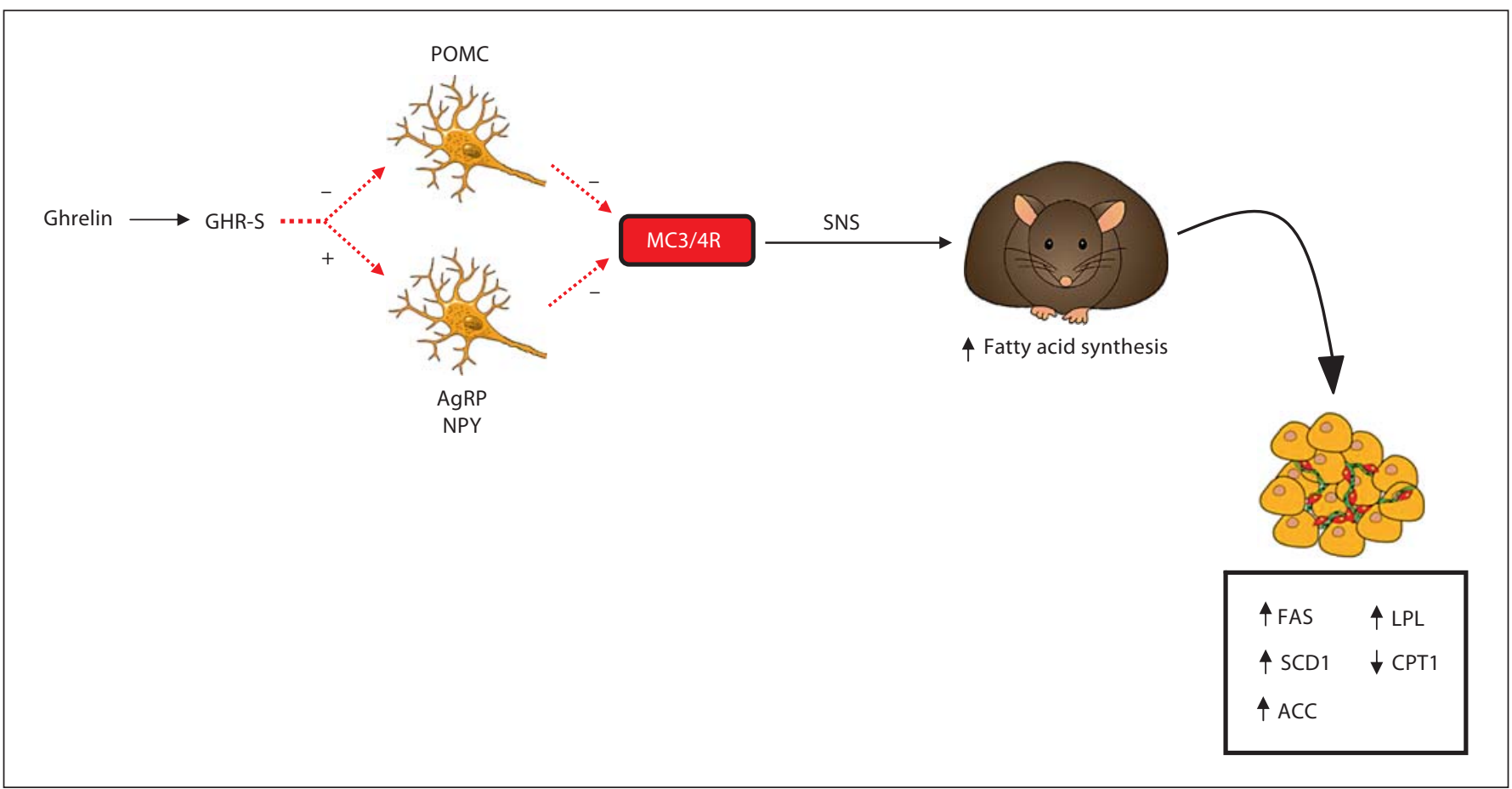

Fig. 4. CNS ghrelin favors peripheral lipid deposition and therefore increases adiposity. The central melanocortin system is one of the most important targets for both hormones and is very likely key for ghrelin and leptin direct actions on adipocyte metabolism. Ghrelin binds to its receptor and hypothalamic neuropep-

Although it was clear that NPY/AgRP were necessary for the actions of ghrelin, it was unknown which specific molecular pathways regulated the expression of these neuropeptides. It has been recently reported that the hypothalamic homeobox domain transcription factor Bsx interacts with the two other transcription factors to activate AgRP and NPY mRNA expression: the forkhead box $\mathrm{O} 1$ and the phosphorylated cAMP response-element binding protein, respectively $[60,61]$. Thus, Bsx, together with forkhead box O1 and phosphorylated cAMP response-element binding protein, plays an essential role in the CNS controlling the hyperphagic responses elicited by ghrelin in both male and female rats $[60,62]$.

Recently, it was also reported that hypothalamic fatty acid metabolism mediates the orexigenic effect of ghrelin $[16,63,64]$. Combining pharmacological and genetic techniques, it was demonstrated that the ghrelin-induced food intake activates hypothalamic sirtuin 1, which deacetylates p53 and thereby activates AMPK [65] (fig. 3). The activation of AMPK subsequently inhibits the synthesis of fatty acids, leading to lower hypothalamic levels tides (NPY/AgRP vs. POMC), and thereby melanocortin receptors are likely involved in the lipogenic action of ghrelin. Red arrows indicate the hypothetical molecular steps which have not been described for the lipogenic action of ghrelin. SCD1 = Stearoyl-CoA-desaturase-1. of malonyl-CoA and increased CPT1 activity [16] (fig. 3). The hypothalamic fatty acid oxidation pathway modulated by AMPK, together with the decrease of FAS expression in the VMH and the activation of CPT1, leads to changes in hypothalamic mitochondrial respiration and production of reactive oxygen species in mice, which are dependent on uncoupling protein 2 [64]. This activation of the mitochondrial mechanism is essential for ghrelininduced mitochondrial proliferation and the activation of NPY/AgRP neurons, ghrelin-triggered synaptic plasticity of POMC neurons, and ghrelin-induced food intake [64] (fig. 3).

\section{CNS Ghrelin and Peripheral Lipid Metabolism}

As mentioned above, one of the most significant actions of ghrelin is to stimulate the development of adiposity [45]. The mechanisms mediating the actions of ghrelin on adipose tissue seem to involve the autonomic nervous system. A single injection of ghrelin in the third cerebral 
ventricle decreases sympathetic nervous activity in brown adipose tissue [52]. On the other hand, chronic central ghrelin infusion increases lipogenic enzyme expression in WAT including FAS, stearoyl-CoA-desaturase-1, ACC $\alpha$ and LPL, whereas it decreases the expression of the fat-oxidation promoting CPT1 in the WAT of rats (fig. 4). Interestingly, these central effects of ghrelin on adipocyte metabolism were tissue-specific and independent of food intake [66]. The molecular pathway linking central ghrelin with adipocytes is the sympathetic nervous system (fig. 4), as demonstrated by the fact that in mice lacking the three main types of $\beta$-adrenoceptors ( $\beta 1, \beta 2$ and $\beta 3$ ), which play a key role in the control of lipolysis, ghrelin failed to modify body weight and did not alter the expression of enzymes regulating lipid synthesis or degradation [66]. Importantly, these effects of central ghrelin on peripheral lipid metabolism are growth hormone-independent [67]. This was demonstrated using a model for the study of growth hormone deficiency. These dwarf rats were centrally treated with ghrelin and showed an increase in body fat [67]. Central ghrelin regulated hepatic lipogenesis de novo in a growth hormone-independent fashion; however, it regulated lipid mobilization in a growth hormone-dependent fashion because CPT1 was decreased only in control rats but not in growth hormone-deficient rats [67]. Concurring with these results was another study that found that chronic treatment with intravenous ghrelin also increased adiposity in rats and these effects were dependent on the GHS-R [68]. Contrarily, a report investigating the acute effects of ghrelin in humans found that lipolysis was increased independently of growth hormone signaling [69].

Another important action of CNS ghrelin is the regulation of cholesterol levels. Daily subcutaneous administration of ghrelin in wild-type mice for 1 week significantly increased total plasma cholesterol levels. Accordingly, the endogenous ghrelin system also has a physiological role in the regulation of cholesterol, as mice lacking ghrelin and ghrelin receptors had reduced circulating cholesterol [70].

\section{CNS Melanocortins and Peripheral Lipid Metabolism}

The melanocortins are a family of peptides produced from the post-translational processing of POMC. This family of neuropeptides possesses a unique feature: they have an endogenous agonist ( $\alpha$-melanocyte-stimulating hormone) and antagonist (AgRP), both of which share common melanocortin receptors. POMC and AgRP neu-

Hypothalamic Control of Lipid Metabolism rons are situated in different neuronal populations of the ARC that function in parallel [71]. Melanocortins act through a family of five members of G-protein-coupled receptors (MCRs) [71]. The most relevant receptors in terms of energy balance regulation are MC3R and MC4R. Receptor agonist delivery into the hypothalamus reduces food intake, body weight and fat mass [3], whereas the administration of receptor antagonists (or inverse agonists) triggers opposite effects [3]. The relevance of the endogenous function of the melanocortin system has been investigated using genetically manipulated mice. Importantly, the phenotypes resulting from mutations in the genes Pomc or Mcr in rodents can be translated to humans. Moreover, mutations in the Mc4r gene are the most common monogenic cause of severe obesity in humans [72].

Recent evidence suggests that the CNS melanocortin system may directly regulate fat metabolism (fig. 2, 4). Anatomical studies have demonstrated that central WAT sympathetic outflow neurons express MC4R [73]. Moreover, the administration of MC3/4R agonists in the CNS decreased body fat in rodents by stimulating lipolysis independent of food intake [74]. Central melanocortins modulate the norepinephrine turnover, which is the principal initiator of lipolysis in mammals. Norepinephrine is released from the sympathetic nerves innervating WAT, and the central injection of a MC3/4R agonist increased the norepinephrine turnover in specific fat depots [75]. The mechanism mediating the action of melanocortins on norepinephrine is mediated by perilipin A and hormone-sensitive lipase, which are essential for norepinephrine-triggered lipolysis [76]. Consistent with this data, treatment with MC3R and MC4R antagonists increased stearoyl-CoA-desaturase-1 expression in WAT [38]. Therefore, blockade of the CNS melanocortin system increased lipid uptake and triglyceride synthesis in the periphery, while stimulation of the CNS melanocortin system increased lipid mobilization in WAT [74]. Interestingly, the pharmacological data obtained from animal models might be of clinical relevance because obese patients deficient in MC4R showed an increased respiratory quotient, implicating melanocortin signaling in the regulation of substrate utilization in humans. With all this data, it is reasonable to hypothesize that impaired central control of nutrient partitioning, lipid deposition and lipid mobilization may contribute to the obesity phenotype in human MC4R deficiency.

Although the physiological effects of the central melanocortin system on fat metabolism are well established, little is known about the molecular pathways mediating 
these actions. A potential candidate for mediating these functions is the sympathetic nervous system because MC4R is located in its efferent neurons that innervate inguinal WAT [73]. This hypothesis was confirmed in a recent report using mice with a complete disruption of $\beta$ adrenergic signaling. When the central melanocortin system was altered in those mice, fat metabolism was unchanged - contrary to the effects observed in wild-type mice [74]. These genetic data were confirmed with electrophysiological studies showing that central stimulation of the CNS melanocortin system increases SNA in WAT, whereas central blockade of CNS melanocortin system has opposite actions [74].

In addition to its actions on WAT, the central melanocortin system also modulates hepatic lipid metabolism. Animals deficient in MC4R show an increased lipogenesis rate and triglyceride content in the liver [77]. Consistently, central administration of MC3/4R agonists reduced hepatic lipogenic gene expression [78], whereas the treatment with MC3/4R antagonists increased hepatic lipogenesis through the stimulation of SREBP-1c and PPAR- $\gamma 2$ [79]. Finally, another issue regarding the central role of melanocortins is their function as an important regulator of cholesterol in rodents. This is an important point because the major plasma lipid abnormality in obesity is elevated triglycerides in the form of very low-density lipoproteins and low high-density lipoprotein cholesterol. The pharmacological or genetic inhibition of the brain's melanocortin system increases circulating highdensity lipoprotein cholesterol by reducing its uptake by the liver independent of food intake or body weight [70]. In this sense, other neuropeptides have also been related to cholesterol metabolism. For instance, when the NPY is centrally administered in rodents, the secretion of triglycerides and, more specifically, very low-density lipoproteins are increased [80].

\section{Conclusions}

The hypothalamus is well known as a crucial regulator of both energy intake and energy expenditure. Studies carried out by different groups over the last years have uncovered novel molecular mechanisms involved in leptin and ghrelin action. One of those pathways involves AMPK-driven changes in hypothalamic lipid metabolism that subsequently influence neuropeptide gene expression. The CNS has also emerged as a relevant regulator of nutrient partitioning, changing the levels of adiposity independent of food intake. The fact that the CNS plays a key role in mediating feeding behavior, energy expenditure and nutrient partitioning reinforces the hypothesis that signals in the CNS are likely the most powerful pathways influencing energy balance. Indeed, these findings describe how endogenous hormones regulate (1) appetite through the AMPK-hypothalamic fatty acid metabolism and (2) peripheral adiposity through the sympathetic nervous system, and open new and exciting pathways for the discovery of a potential candidate drug target to fight obesity.

\section{Future Directions}

Several anatomical, pharmacological, genetic and physiological studies have demonstrated that specific hypothalamic neuronal populations regulate peripheral lipid metabolism. Although this brief review is focused on leptin, ghrelin and melanocortins, many other signals including glucagon-like peptide 1 , resistin, insulin and NPY are also involved in the brain-adipose tissue crosstalk [11]. All these metabolic signals interact between them, making their molecular pathways complex and redundant. This might be the case for leptin and ghrelin, which signal through the same hypothalamic neuronal populations to trigger their biological actions. However, those two signals balance each other by having opposite actions $[81,82]$.

There are still some remaining issues that need to be addressed. For example, it is well established that leptin decreases NPY/AgRP expression and activates POMC activity, thereby leading to diminished feeding behavior, whereas ghrelin exerts opposite actions causing increased appetite. However, it is not fully clarified if the central actions of leptin and ghrelin controlling peripheral metabolism are mediated by these neuronal networks. Further studies assessing the metabolic actions of leptin and ghrelin in rodents with disrupted NPY/AgRP or POMC neuronal populations will help to understand if both hormones share common hypothalamic neural circuits to control food intake and peripheral metabolism.

Similar questions may be applied for the specific hypothalamic nuclei involved in mediating their actions. For example, it is clear that leptin requires the arcuate, ventromedial and paraventricular nuclei for decreasing feeding behavior, but the neurons commanding its peripheral actions are still poorly understood. Therefore, even though during the last years we have started to learn how the CNS controls hypothalamic and peripheral metabolism, there are some black boxes that need further 
attention. Similarly, there is a general lack of knowledge on how different diets, gender and/or ageing influence the central control of peripheral lipid metabolism. Studies addressing the consequences of disruption of these central mechanisms on endpoints such as fat mass, liver steatosis and circulating levels of different biomarkers linked to cardiovascular risk are clearly needed. The precise knowledge of the metabolic brain-periphery crosstalk might allow for the development of drug targets for the treatment of obesity and its associated comorbidities.

\section{Acknowledgements}

This work has been supported by grants from Fondo Investigationes Sanitarias (M.L.: PS09/01880), Ministerio de Ciencia e Innovación (C.D.: BFU2008-02001; M.L.: RyC-2007-00211; R.N.: RyC-2008-02219 and SAF2009-07049), Xunta de Galicia (M.L.: 10PXIB208164PR; R.N.: 2010/14) and the European Union (C.D., M.L. and R.N.: Health-Neurofast). CIBER de Fisiopatología de la Obesidad y Nutrición is an initiative of ISCIII.

\section{References}

1 Flier JS: Obesity wars: molecular progress confronts an expanding epidemic. Cell 2004; 116:337-350.

2 van den Top M, Lee K, Whyment AD, Blanks AM, Spanswick D: Orexigen-sensitive NPY/ AgRP pacemaker neurons in the hypothalamic arcuate nucleus. Nat Neurosci 2004;7: 493-494.

- 3 Fan W, Boston BA, Kesterson RA, Hruby VJ, Cone RD: Role of melanocortinergic neurons in feeding and the agouti obesity syndrome. Nature 1997;385:165-168.

$\checkmark 4$ Cowley MA, Smart JL, Rubinstein M, Cerdan MG, Diano S, Horvath TL, Cone RD, Low MJ: Leptin activates anorexigenic POMC neurons through a neural network in the arcuate nucleus. Nature 2001;411:480484.

5 Qiu J, Fang Y, Ronnekleiv OK, Kelly MJ: Leptin excites proopiomelanocortin neurons via activation of TRPC channels. J Neurosci 2010;30:1560-1565.

6 Nakazato M, Murakami N, Date Y, Kojima M, Matsuo H, Kangawa K, Matsukura S: A role for ghrelin in the central regulation of feeding. Nature 2001;409:194-198.

7 Bamshad M, Aoki VT, Adkison MG, Warren WS, Bartness TJ: Central nervous system origins of the sympathetic nervous system outflow to white adipose tissue. Am J Physiol 1998;275:R291-R299.

8 Bamshad M, Song CK, Bartness TJ: CNS origins of the sympathetic nervous system outflow to brown adipose tissue. Am J Physiol 1999;276:R1569-R1578.

9 Kreier F, Fliers E, Voshol PJ, Van Eden CG, Havekes LM, Kalsbeek A, Van Heijningen CL, Sluiter AA, Mettenleiter TC, Romijn JA, Sauerwein HP, Buijs RM: Selective parasympathetic innervation of subcutaneous and intra-abdominal fat - functional implications. J Clin Invest 2002;110:1243-1250.
10 Kreier F, Kap YS, Mettenleiter TC, van Heijningen C, van der Vliet J, Kalsbeek A, Sauerwein HP, Fliers E, Romijn JA, Buijs RM: Tracing from fat tissue, liver, and pancreas: a neuroanatomical framework for the role of the brain in type 2 diabetes. Endocrinology 2006; 147:1140-1147.

-11 Nogueiras R, Lopez M, Dieguez C: Regulation of lipid metabolism by energy availability: a role for the central nervous system. Obes Rev 2010;11:185-201.

12 Lage R, Dieguez C, Vidal-Puig A, Lopez M: AMPK: a metabolic gauge regulating wholebody energy homeostasis. Trends Mol Med 2008; 14:539-549.

$13 \mathrm{Hu}$ Z, Cha SH, Chohnan S, Lane MD: Hypothalamic malonyl-CoA as a mediator of feeding behavior. Proc Natl Acad Sci USA 2003; 100:12624-12629.

14 Loftus TM, Jaworsky DE, Frehywot GL, Townsend CA, Ronnett GV, Lane MD, Kuhajda FP: Reduced food intake and body weight in mice treated with fatty acid synthase inhibitors. Science 2000;288:23792381.

15 Lopez M, Lelliott CJ, Tovar S, Kimber W, Gallego R, Virtue S, Blount M, Vazquez MJ, Finer N, Powles TJ, O’Rahilly S, Saha AK, Dieguez C, Vidal-Puig AJ: Tamoxifen-induced anorexia is associated with fatty acid synthase inhibition in the ventromedial nucleus of the hypothalamus and accumulation of malonyl-CoA. Diabetes 2006;55:1327-1336.

16 Lopez M, Lage R, Saha AK, Perez-Tilve D, Vazquez MJ, Varela L, Sangiao-Alvarellos S, Tovar S, Raghay K, Rodriguez-Cuenca S, Deoliveira RM, Castaneda T, Datta R, Dong JZ, Culler M, Sleeman MW, Alvarez CV, Gallego R, Lelliott CJ, Carling D, Tschop MH, Dieguez $\mathrm{C}$, Vidal-Puig A: Hypothalamic fatty acid metabolism mediates the orexigenic action of ghrelin. Cell Metab 2008;7:389-399.

17 Poplawski MM, Mastaitis JW, Yang XJ, Mobbs CV: Hypothalamic responses to fasting indicate metabolic reprogramming away from glycolysis toward lipid oxidation. Endocrinology;151:5206-5217.
8 Chakravarthy MV, Zhu Y, Lopez M, Yin L, Wozniak DF, Coleman T, Hu Z, Wolfgang M, Vidal-Puig A, Lane MD, Semenkovich CF: Brain fatty acid synthase activates PPARalpha to maintain energy homeostasis. J Clin Invest 2007;117:2539-2552.

-19 Minokoshi Y, Alquier T, Furukawa N, Kim YB, Lee A, Xue B, Mu J, Foufelle F, Ferre P, Birnbaum MJ, Stuck BJ, Kahn BB: AMP-kinase regulates food intake by responding to hormonal and nutrient signals in the hypothalamus. Nature 2004;428:569-574.

20 Obici S, Feng Z, Arduini A, Conti R, Rossetti L: Inhibition of hypothalamic carnitine palmitoyltransferase-1 decreases food intake and glucose production. Nat Med 2003; 9:756-761.

21 Pocai A, Lam TK, Obici S, Gutierrez-Juarez R, Muse ED, Arduini A, Rossetti L: Restoration of hypothalamic lipid sensing normalizes energy and glucose homeostasis in overfed rats. J Clin Invest 2006;116:1081-1091.

22 Wolfgang MJ, Kurama T, Dai Y, Suwa A, Asaumi M, Matsumoto S, Cha SH, Shimokawa T, Lane MD: The brain-specific carnitine palmitoyltransferase-1c regulates energy homeostasis. Proc Natl Acad Sci USA 2006;103:7282-7287.

23 Gao S, Kinzig KP, Aja S, Scott KA, Keung W, Kelly S, Strynadka K, Chohnan S, Smith WW, Tamashiro KL, Ladenheim EE, Ronnett GV, Tu Y, Birnbaum MJ, Lopaschuk GD, Moran TH: Leptin activates hypothalamic acetyl-CoA carboxylase to inhibit food intake. Proc Natl Acad Sci USA 2007;104: 17358-17363.

24 Lopez M, Varela L, Vazquez MJ, RodriguezCuenca S, Gonzalez CR, Velagapudi VR, Morgan DA, Schoenmakers E, Agassandian K, Lage R, Martinez de Morentin PB, Tovar S, Nogueiras R, Carling D, Lelliott C, Gallego R, Oresic M, Chatterjee K, Saha AK, Rahmouni K, Dieguez C, Vidal-Puig A: Hypothalamic AMPK and fatty acid metabolism mediate thyroid regulation of energy balance. Nat Med 2010;16:1001-1008. 
-25 Cha SH, Wolfgang M, Tokutake Y, Chohnan S, Lane MD: Differential effects of central fructose and glucose on hypothalamic malonyl-CoA and food intake. Proc Natl Acad Sci USA 2008;105:16871-16875.

26 McCrimmon RJ, Fan X, Ding Y, Zhu W, Jacob RJ, Sherwin RS: Potential role for AMPactivated protein kinase in hypoglycemia sensing in the ventromedial hypothalamus. Diabetes 2004;53:1953-1958.

27 Kim MS, Park JY, Namkoong C, Jang PG, Ryu JW, Song HS, Yun JY, Namgoong IS, Ha J, Park IS, Lee IK, Viollet B, Youn JH, Lee HK, Lee KU: Anti-obesity effects of alpha-lipoic acid mediated by suppression of hypothalamic AMP-activated protein kinase. Nat Med 2004;10:727-733.

-28 Stoppa GR, Cesquini M, Roman EA, Prada PO, Torsoni AS, Romanatto T, Saad MJ, Velloso LA, Torsoni MA: Intracerebroventricular injection of citrate inhibits hypothalamic AMPK and modulates feeding behavior and peripheral insulin signaling. J Endocrinol 2008;198:157-168.

29 Cha SH, Lane MD: Central lactate metabolism suppresses food intake via the hypothalamic amp kinase/malonyl-CoA signaling pathway. Biochem Biophys Res Commun 2009;386:212-216.

30 Lam TK, Schwartz GJ, Rossetti L: Hypothalamic sensing of fatty acids. Nat Neurosci 2005;8:579-584.

- 31 Frederich RC, Lollmann B, Hamann A, Napolitano-Rosen A, Kahn BB, Lowell BB, Flier JS: Expression of ob mRNA and its encoded protein in rodents. Impact of nutrition and obesity. J Clin Invest 1995;96:1658-1663.

- 32 Zhang Y, Proenca R, Maffei M, Barone M, Leopold L, Friedman JM: Positional cloning of the mouse obese gene and its human homologue. Nature 1994;372:425-432.

33 Siegrist-Kaiser CA, Pauli V, Juge-Aubry CE, Boss O, Pernin A, Chin WW, Cusin I, Rohner-Jeanrenaud F, Burger AG, Zapf J, Meier CA: Direct effects of leptin on brown and white adipose tissue. J Clin Invest 1997;100: 2858-2864.

-34 Fruhbeck G, Aguado M, Martinez JA: In vitro lipolytic effect of leptin on mouse adipocytes: evidence for a possible autocrine/paracrine role of leptin. Biochem Biophys Res Commun 1997;240:590-594.

- 35 Kamohara S, Burcelin R, Halaas JL, Friedman JM, Charron MJ: Acute stimulation of glucose metabolism in mice by leptin treatment. Nature 1997;389:374-377.

- 36 Fruhbeck G, Aguado M, Gomez-Ambrosi J, Martinez JA: Lipolytic effect of in vivo leptin administration on adipocytes of lean and ob/ ob mice, but not db/db mice. Biochem Biophys Res Commun 1998;250:99-102.

- 37 Buettner C, Muse ED, Cheng A, Chen L, Scherer T, Pocai A, Su K, Cheng B, Li X, Harvey-White J, Schwartz GJ, Kunos G, Rossetti L: Leptin controls adipose tissue lipogenesis via central, STAT3-independent mechanisms. Nat Med 2008;14:667-675.
8 Lin J, Choi YH, Hartzell DL, Li C, Della-Fera MA, Baile CA: CNS melanocortin and leptin effects on stearoyl-CoA desaturase- 1 and resistin expression. Biochem Biophys Res Commun 2003;311:324-328.

39 Gallardo N, Bonzon-Kulichenko E, Fernandez-Agullo T, Molto E, Gomez-Alonso S, Blanco P, Carrascosa JM, Ros M, Andres A: Tissue-specific effects of central leptin on the expression of genes involved in lipid metabolism in liver and white adipose tissue. Endocrinology 2007; 148:5604-5610.

40 Tajima D, Masaki T, Hidaka S, Kakuma T, Sakata T, Yoshimatsu H: Acute central infusion of leptin modulates fatty acid mobilization by affecting lipolysis and $m$ RNA expression for uncoupling proteins. Exp Biol Med (Maywood) 2005;230:200-206.

41 Prieur X, Tung YC, Griffin JL, Farooqi IS, O'Rahilly S, Coll AP: Leptin regulates peripheral lipid metabolism primarily through central effects on food intake. Endocrinology $2008 ; 149: 5432-5439$.

42 El-Haschimi K, Pierroz DD, Hileman SM, Bjorbaek C, Flier JS: Two defects contribute to hypothalamic leptin resistance in mice with diet-induced obesity. J Clin Invest 2000; 105:1827-1832.

43 Caro JF, Kolaczynski JW, Nyce MR, Ohannesian JP, Opentanova I, Goldman WH, Lynn RB, Zhang PL, Sinha MK, Considine RV: Decreased cerebrospinal-fluid/serum leptin ratio in obesity: a possible mechanism for leptin resistance. Lancet 1996;348:159161.

44 Munzberg H, Myers MG Jr: Molecular and anatomical determinants of central leptin resistance. Nat Neurosci 2005;8:566-570.

45 Tschop M, Smiley DL, Heiman ML: Ghrelin induces adiposity in rodents. Nature 2000; 407:908-913.

46 Wren AM, Small CJ, Ward HL, Murphy KG, Dakin CL, Taheri S, Kennedy AR, Roberts GH, Morgan DG, Ghatei MA, Bloom SR: The novel hypothalamic peptide ghrelin stimulates food intake and growth hormone secretion. Endocrinology 2000;141:4325-4328.

47 Tschop M, Weyer C, Tataranni PA, Devanarayan V, Ravussin E, Heiman ML: Circulating ghrelin levels are decreased in human obesity. Diabetes 2001;50:707-709.

48 Otto B, Cuntz U, Fruehauf E, Wawarta R, Folwaczny C, Riepl RL, Heiman ML, Lehnert P, Fichter M, Tschop M: Weight gain decreases elevated plasma ghrelin concentrations of patients with anorexia nervosa. Eur J Endocrinol 2001;145:669-673.

49 Cummings DE, Clement K, Purnell JQ, Vaisse C, Foster KE, Frayo RS, Schwartz MW, Basdevant A, Weigle DS: Elevated plasma ghrelin levels in Prader Willi syndrome. Nat Med 2002;8:643-644.

50 Wortley KE, del Rincon JP, Murray JD, Garcia K, Iida K, Thorner MO, Sleeman MW: Absence of ghrelin protects against earlyonset obesity. J Clin Invest 2005;115:35733578.
1 Zigman JM, Nakano Y, Coppari R, Balthasar $\mathrm{N}$, Marcus JN, Lee CE, Jones JE, Deysher AE, Waxman AR, White RD, Williams TD, Lachey JL, Seeley RJ, Lowell BB, Elmquist JK: Mice lacking ghrelin receptors resist the development of diet-induced obesity. J Clin Invest $2005 ; 115: 3564-3572$.

- 52 van der Lely AJ, Tschop M, Heiman ML, Ghigo E: Biological, physiological, pathophysiological, and pharmacological aspects of ghrelin. Endocr Rev 2004;25:426-457.

53 Gutierrez JA, Solenberg PJ, Perkins DR, Willency JA, Knierman MD, Jin Z, Witcher DR, Luo S, Onyia JE, Hale JE: Ghrelin octanoylation mediated by an orphan lipid transferase. Proc Natl Acad Sci USA 2008; 105:6320-6325.

54 Yang J, Brown MS, Liang G, Grishin NV, Goldstein JL: Identification of the acyltransferase that octanoylates ghrelin, an appetitestimulating peptide hormone. Cell 2008;132: 387-396.

55 Sun Y, Asnicar M, Saha PK, Chan L, Smith RG: Ablation of ghrelin improves the diabetic but not obese phenotype of ob/ob mice. Cell Metab 2006;3:379-386.

56 Guan XM, Yu H, Palyha OC, McKee KK, Feighner SD, Sirinathsinghji DJ, Smith RG, Van der Ploeg LH, Howard AD: Distribution of mRNA encoding the growth hormone secretagogue receptor in brain and peripheral tissues. Brain Res Mol Brain Res 1997;48:2329.

57 Nogueiras R, Tovar S, Mitchell SE, Rayner DV, Archer ZA, Dieguez C, Williams LM: Regulation of growth hormone secretagogue receptor gene expression in the arcuate nuclei of the rat by leptin and ghrelin. Diabetes 2004;53:2552-2558.

58 Cowley MA, Smith RG, Diano S, Tschop M Pronchuk N, Grove KL, Strasburger CJ, Bidlingmaier $\mathrm{M}$, Esterman $\mathrm{M}$, Heiman $\mathrm{ML}$, Garcia-Segura LM, Nillni EA, Mendez P, Low MJ, Sotonyi P, Friedman JM, Liu H, Pinto S, Colmers WF, Cone RD, Horvath TL: The distribution and mechanism of action of ghrelin in the CNS demonstrates a novel hypothalamic circuit regulating energy homeostasis. Neuron 2003;37:649-661.

59 Chen HY, Trumbauer ME, Chen AS, Weingarth DT, Adams JR, Frazier EG, Shen Z, Marsh DJ, Feighner SD, Guan XM, Ye Z, Nargund RP, Smith RG, Van der Ploeg LH, Howard AD, MacNeil DJ, Qian S: Orexigenic action of peripheral ghrelin is mediated by neuropeptide $\mathrm{Y}$ and agouti-related protein. Endocrinology 2004;145:2607-2612.

60 Sakkou M, Wiedmer P, Anlag K, Hamm A, Seuntjens E, Ettwiller L, Tschop MH, Treier M: A role for brain-specific homeobox factor Bsx in the control of hyperphagia and locomotory behavior. Cell Metab 2007;5:450463 
-61 Lage R, Vazquez MJ, Varela L, Saha AK, Vidal-Puig A, Nogueiras R, Dieguez C, Lopez M: Ghrelin effects on neuropeptides in the rat hypothalamus depend on fatty acid metabolism actions on BSX but not on gender. FASEB J 2010;24:2670-2679.

-62 Nogueiras R, Lopez M, Lage R, Perez-Tilve D, Pfluger P, Mendieta-Zeron H, Sakkou M, Wiedmer P, Benoit SC, Datta R, Dong JZ, Culler M, Sleeman M, Vidal-Puig A, Horvath T, Treier M, Dieguez C, Tschop MH: Bsx, a novel hypothalamic factor linking feeding with locomotor activity, is regulated by energy availability. Endocrinology 2008; 149:3009-3015.

-63 Kola B, Hubina E, Tucci SA, Kirkham TC, Garcia EA, Mitchell SE, Williams LM, Hawley SA, Hardie DG, Grossman AB, Korbonits M: Cannabinoids and ghrelin have both central and peripheral metabolic and cardiac effects via amp-activated protein kinase. J Biol Chem 2005;280:25196-25201.

-64 Andrews ZB, Liu ZW, Walllingford N, Erion DM, Borok E, Friedman JM, Tschop MH, Shanabrough M, Cline G, Shulman GI, Coppola A, Gao XB, Horvath TL, Diano S: UCP2 mediates ghrelin's action on NPY/AgRP neurons by lowering free radicals. Nature 2008;454:846-851.

-65 Velasquez DA, Martinez G, Romero A, Vazquez MJ, Boit KD, Dopeso-Reyes IG, Lopez M, Vidal A, Nogueiras R, Dieguez C: The central sirtuin $1 / \mathrm{p} 53$ pathway is essential for the orexigenic action of ghrelin. Diabetes 2011;60:1177-1185.

66 Theander-Carrillo C, Wiedmer P, CettourRose P, Nogueiras R, Perez-Tilve D, Pfluger P, Castaneda TR, Muzzin P, Schurmann A, Szanto I, Tschop MH, Rohner-Jeanrenaud F: Ghrelin action in the brain controls adipocyte metabolism. J Clin Invest 2006;116: 1983-1993.
67 Sangiao-Alvarellos S, Vazquez MJ, Varela L, Nogueiras R, Saha AK, Cordido F, Lopez M, Dieguez C: Central ghrelin regulates peripheral lipid metabolism in a growth hormoneindependent fashion. Endocrinology 2009; 150:4562-4574.

68 Davies JS, Kotokorpi P, Eccles SR, Barnes SK, Tokarczuk PF, Allen SK, Whitworth HS, Guschina IA, Evans BA, Mode A, Zigman JM, Wells T: Ghrelin induces abdominal obesity via GHS-R-dependent lipid retention. Mol Endocrinol 2009;23:914-924.

69 Vestergaard ET, Gormsen LC, Jessen N, Lund S, Hansen TK, Moller N, Jorgensen JO Ghrelin infusion in humans induces acute insulin resistance and lipolysis independent of growth hormone signaling. Diabetes 2008;57:3205-3210.

70 Perez-Tilve D, Hofmann SM, Basford J, Nogueiras R, Pfluger PT, Patterson JT, Grant E, Wilson-Perez HE, Granholm NA, Arnold M, Trevaskis JL, Butler AA, Davidson WS, Woods SC, Benoit SC, Sleeman MW, DiMarchi RD, Hui DY, Tschop MH: Melanocortin signaling in the CNS directly regulates circulating cholesterol. Nat Neurosci;13:877882.

71 Cone RD: Anatomy and regulation of the central melanocortin system. Nat Neurosci 2005;8:571-578.

72 Farooqi IS, O’Rahilly S: Genetic factors in human obesity. Obes Rev 2007;8(Suppl 1): 37-40.

73 Song CK, Jackson RM, Harris RB, Richard $\mathrm{D}$, Bartness TJ: Melanocortin-4 receptor mRNA is expressed in sympathetic nervous system outflow neurons to white adipose tissue. Am J Physiol Regul Integr Comp Physiol 2005;289:R1467-R1476.

74 Nogueiras R, Wiedmer P, Perez-Tilve D, Veyrat-Durebex C, Keogh JM, Sutton GM, Pfluger PT, Castaneda TR, Neschen S, Hofmann SM, Howles PN, Morgan DA, Benoit SC, Szanto I, Schrott B, Schurmann A, Joost HG, Hammond C, Hui DY, Woods SC, Rahmouni K, Butler AA, Farooqi IS, O’Rahilly S, Rohner-Jeanrenaud F, Tschop MH: The central melanocortin system directly controls peripheral lipid metabolism. J Clin Invest 2007;117:3475-3488.
Brito MN, Brito NA, Baro DJ, Song CK, Bartness TJ: Differential activation of the sympathetic innervation of adipose tissues by melanocortin receptor stimulation. Endocrinology 2007;148:5339-5347.

76 Shrestha YB, Vaughan CH, Smith BJ Jr, Song CK, Baro DJ, Bartness TJ: Central melanocortin stimulation increases phosphorylated perilipin A and hormone-sensitive lipase in adipose tissues. Am J Physiol Regul Integr Comp Physiol 2010;299:R140-R149.

-77 Albarado DC, McClaine J, Stephens JM, Mynatt RL, Ye J, Bannon AW, Richards WG, Butler AA: Impaired coordination of nutrient intake and substrate oxidation in melanocortin-4 receptor knockout mice. Endocrinology 2004;145:243-252.

78 Li G, Zhang Y, Rodrigues E, Zheng D, Matheny M, Cheng KY, Scarpace PJ: Melanocortin activation of nucleus of the solitary tract avoids anorectic tachyphylaxis and induces prolonged weight loss. Am J Physiol Endocrinol Metab 2007;293:E252-E258.

79 Poritsanos NJ, Wong D, Vrontakis ME, Mizuno TM: Regulation of hepatic PPARgamma2 and lipogenic gene expression by melanocortin. Biochem Biophys Res Commun 2008;376:384-388.

80 Stafford JM, Yu F, Printz R, Hasty AH, Swift LL, Niswender KD: Central nervous system neuropeptide Y signaling modulates VLDL triglyceride secretion. Diabetes 2008;57: 1482-1490.

81 Nogueiras R, Tschop MH, Zigman JM: Central nervous system regulation of energy metabolism: ghrelin versus leptin. Ann NY Acad Sci 2008;1126:14-19.

82 Zigman JM, Elmquist JK: Minireview: From anorexia to obesity - the yin and yang of body weight control. Endocrinology 2003; 144:3749-3756. 